\title{
Parasitic Infections of the African Giant Rat (Cricetomys Gambianus) in the Semi-Arid Region of Northeastern, Nigeria
}

\author{
${ }^{1}$ MBAYA*, A.W., ${ }^{2}$ KUMSHE, H. A., ${ }^{1}$ LUKA, J. and ${ }^{1}$ MADARA, A. M.
}

${ }^{1}$ Department of Veterinary Microbiology and Parasitology, ${ }^{2}$ Department of Veterinary Medicine, Faculty of Veterinary Medicine, University of Maiduguri, P.M.B. 1069 Maiduguri, Borno State, Nigeria. Corresponding author: awmbaya@yahoo.com, +234 803601174;

\section{SUMMARY}

A study of the internal and external parasites infections of the African giant rat (Cricetomys gambianus) was undertaken using standard parasitological methods. Of the 100 wild giant rats captured, 22(43.14\%) males and $16(32.65 \%)$ females harboured gastrointestinal parasites. Similarly, 14(31.11\%) juveniles and 24(43.64\%) adults were also infected. The various species of gastrointestinal parasites recovered from the giant rats at post-mortem were Hymenolepis nana 19(50\%), Ancylostoma caninum 4(10.53\%), Strongyloides stercoralis 7(18.42\%), Aspicularis tetraptera 5(13.16\%) and Taenia cysts $3(7.89 \%)$. The post-mortem worm counts showed that Hymenolepis nana had the highest burden than the other helminths. At the same time, 12(23.53\%) males, 10(20.41) females, $14(31.11 \%)$ juveniles and $8(14.55 \%$ ) adults also harboured various degree of ectoparasitic infestations. № statistical variation was observed on the prevalence of ectoparasitic infestations according to sex $(p>0.05)$ however, juveniles $14(31.11 \%)$ were significantly $(\mathbb{P}<0.05)$ more infested than the adults $8(14.55 \%)$. Similarly, adults $24(43.64 \%)$ were significantly $(p<0.05)$ more infected with gastrointestinal parasites than juveniles $14(31.11 \%)$. The results also showed that $11(50 \%)$ had Rhipicephalus sanguineus, 5(22.73\%) Xenopsylla cheopis, 3(13.64\%) Ctenocephalides canis, 2(50\%) Polyplax serrata and 1(4.55\%) Ixodes rasus. In addition, 13(25.49\%) males, $12(24.49 \%)$ females, $10(22.22 \%)$ juveniles and $15(27.27 \%)$ adults harboured various haemoparasites. Hepatozoan muris was found in $13(52 \%)$, Eperythrozoon coccoides in $4(18 \%)$ and Haemobartonella muris in $8(32 \%)$. It was therefore, concluded that the giant rats in the semi-arid region of Northeastern, Nigeria, harbour parasites of medical and veterinary importance.

KEY WORDS: Parasites, African giant rat, Semi-arid region, Nigeria

\section{INTRODUCTION}

The African giant rat (Cricetomys gambianus) serves to keep insect population under control, and act as transporters of seeds from different plants (Joo and Myers, 2004). However, they are useful in biomedical research and provide a wealth of information on rodent physiology and behaviour (Ajayi, 1977; Kingdon, 1989; Nowak, 1997; Audu et al., 2008). In spite of their economic importance, the rat's close association with man ensures a 'synantropic-zoonotic' association while a 'sylvatic-zoonotic' association may occur with wild pigs and man on the other hand (Joo and Myers, 2004). As such, several researchers deduced that, the giant rat, Rodentia cricetomyinae, with its worldwide distribution, might serve as a reservoir host of parasites of medical and veterinary importance (Dipeolu and Ajayi, 1976; Ajayi, 1977; Kingdon, 1989; Joo and Myers, 2004). A study on the parasites of the giant rat conducted by Joo and Myers (2004) also showed heavy presence of Strongyloides and a few cestodes among other parasites. Ectoparasites commonly encountered among Gambian rats were the black rat flea; Xenopsylla cheopis, Ixodes rasus and Ornithonyssus bacoti while the endoparasites encountered were mainly, Aspicularis tetraptera and Hymenolepis species, with the later being zoonotic in nature (Joo and Myers, 2004). The parasites of the giant rat have been established in the Democratic Republic of Congo (Bobe and Mabella, 1997), in Southwestern Nigeria (Dipeolu and Ajayi, 1976; Ajayi, 1977), in Eastern Nigeria (Okoye and Rose, 2008) and in Zaria, where, Chineme and Ibrahim (1994) reported hepatic capillariasis in the rats. Similarly, Taenia serialis cysts were recovered from the bodies of two captured African giant rats in the United States (Claude et al., 2005). Of greater concern are human infections with Angiostrongylus cantonensis, the giant rat lungworm that is known to cause eosinophilic meningitis in humans (Anne, 
2009). In-spite of these reports, there is a paucity of information regarding parasites of the wild rodents in the semi-arid region of Northeastern Nigeria. The semi-arid region of Northeastern Nigeria holds the largest concentration of livestock in the country (Bourn et al., 1994) and a place where giant rats are served as delicacy. This study was therefore, designed to study the internal, external as well as the haemoparasitic infections of the African giant rat (Cricetomys gambianus) in the semi-arid region of northeastern Nigeria, with a view of knowing its zoonotic implication and for enhancing its exsitu conservation.

\section{MATERIALS AND METHODS Survey area}

The survey was conducted in Maiduguri city and its environs, located between latitude $115^{\circ} \mathrm{N}$ and longitude $135^{\circ} \mathrm{E}$. It occupies an area of 50, 778 square kilometres, and shares international borders with the Republic of Niger to the North, Chad to the Northeast and Cameroon to the East (Elumere, 1987). The climate has March - April as the hottest period of the year with temperature ranging between $30^{\circ} \mathrm{C}-40^{\circ} \mathrm{C}$. The area under survey is semi-arid and is usually cold and dry during the months of November January (Elumere, 1987). The captured wild African giant rats (Cricetomys gambianus) were mainly, from Sanda Kyarimi Zoological Garden, Maimalari Army Barrack, University of Maiduguri Staff Quarters, Baga Road Area and Custom Area.

\section{Animals}

One hundred (100) wild African giant rats (Cricetomys gambianus) of both sexes and ages and weighing between 1.2 to $1.87 \mathrm{~kg}$ were used for the survey. They were trapped from various locations within the semi-arid region of Northeastern, Nigeria using special traps designed by Havahart ${ }^{\circledR}$, Ossining, New York, USA. They were placed in metal cages in a flyproof room in the Parasitology Laboratory, Faculty of Veterinary Medicine, University of Maiduguri, Nigeria and pelleted feeds (Vital, Nigeria, PLc. Jos, Nigeria) water was provided ad-libitum. The rodents were allowed 40 days to acclimatize to their new environment before the commencement of the study and were handled in accordance with internationally accepted principles for the use of laboratory animals for biomedical research (Broom and Legge, 2004).

\section{Examination for ectoparasites}

Ectoparasites were collected using formalin soaked cotton wool wrapped on a pair of forceps. The ectoparasites recovered were cleared in xylol, mounted in Canada balsam on a clean slide, and identified using standard methods (Soulsby, 1982).

\section{Examination for haemoparasites}

In all cases, blood samples were collected through tail vein. Thick, thin and buffy-coat smears were routinely stained with $10 \%$ Giemsa stain and examined for haemoparasites (Levine, 1973; Soulsby, 1982). The number of red cells parasitized was counted and the mean values obtained (Pratt, 1987; Mbaya et al., 2008).

\section{Examination for helminths}

After sacrifice and subsequent evisceration, the various segments of the gastrointestinal tract (oesophagus, stomach, small intestine, large intestine, colon and rectum) were opened separately and their mucosae scraped with their contents. Helminths were, recovered from the various portions of the gastrointestinal tract by settling and decanting method and post-mortem worm counts determined (Hansen and Perry, 1994). Similarly, abdominal cavities were examined for presence of cestodes. The parasites recovered were processed using standard methods (Soulsby, 1982). The identification of the parasites was based on standard morphological characteristics (Soulsby, 1982).

\section{Statistical analysis}

Data obtained were summarized as means \pm standard deviation or percentages. $\mathrm{P}<0.05$ were considered significant at 95\% confidence limit (Maed and Curnow, 1983).

\section{RESULTS}

Table I shows the prevalence of gastrointestinal, ecto and haemoparites of African giant rats examined in the semi-arid region of northeastern, Nigeria, according to sex and age. Out of the 51 males examined, 22(43.14\%), $12(23.53 \%)$ and $13(25.49 \%)$ harboured gastrointestinal, ectoparasites and haemoparasites respectively. Similarly, out of the 49 females examined, 16(32.65\%), 10(20.41\%) and $12(24.49 \%)$ harboured gastrointestinal, 
ectoparasites and haemoparasites respectively. Among the 45 juveniles examined, 14(31.11\%), $14(31.11 \%)$ and $10(22.22 \%)$ were infected with gastrointestinal, ectoparasites and haemoparasites respectively, while out of the 55 adults examined, 24(43.64\%), 8(14.55\%) and $15(27.27 \%)$ were infected with gastrointestinal, ectoparasites and haemoparasites respectively. Males and adults were significantly $(\mathrm{p}<0.05)$ more infected with the parasites than their counterparts.

The various species of gastrointestinal parasites encountered in the African giant rats in this study are presented in Table II. Out of the 38 infected rats, 19(50\%) harboured Hymenolepis nana, with a post-mortem worm count of $255.6 \pm 0.07$, while $7(18.42 \%)$ harboured Strongyloides stercoralis with a mean count of $126.5 \pm 0.05$. Similarly, 5(13.16\%) harboured Aspicularis tetraptera with a count of $105.2 \pm 0.05$ and 4(10.53\%) harboured Ancylostoma caninum with a count of $76.4 \pm 0.04$ while $4(10.53 \%)$ harboured Taenia species cysts in the abdominal cavity with a mean count of $8.0 \pm 0.01$.

TABLE I: Prevalence of gastrointestinal, ecto and haemoparasites of African giant rats (Cricetomys gambianus) examined in the semi-arid region of northeastern, Nigeria

\begin{tabular}{|c|c|c|c|c|}
\hline \multirow[t]{2}{*}{ Parameters } & \multirow{2}{*}{$\begin{array}{l}\text { No. } \\
\text { Examined }\end{array}$} & \multicolumn{3}{|c|}{ No. Infected (\%) } \\
\hline & & $\begin{array}{l}\text { Gastro- } \\
\text { intestinal } \\
\text { parasites }\end{array}$ & Ectoparasites & Haemoparasites \\
\hline Male & 51 & $22(43.14 \%)^{\mathrm{a}}$ & $12(23.53 \%)^{\mathrm{a}}$ & $13(25.49 \%)^{\mathrm{a}}$ \\
\hline Sex $_{\text {Female }}$ & 49 & $16(32.65 \%)^{b}$ & $10(20.41 \%)^{\mathrm{a}}$ & $12(24.49 \%)^{\mathrm{a}}$ \\
\hline Total & 100 & $38(38.0 \%)$ & $22(22.0 \%)$ & $25(25.0 \%)$ \\
\hline Juveniles & 45 & $14(31.11 \%)^{\mathrm{a}}$ & $14(31.11 \%)^{a}$ & $10(22.22 \%)^{\mathrm{a}}$ \\
\hline $\begin{array}{l}\text { Age } \\
\text { Adult }\end{array}$ & 55 & $24(43.64 \%)^{b}$ & $8(14.55 \%)^{b}$ & $15(27.27 \%)^{b}$ \\
\hline Total & 100 & $38(38.0 \%)$ & $22(22.0 \%)$ & $25(25.0 \%)$ \\
\hline
\end{tabular}

${ }^{a, b}$ Superscripts in columns differed significantly $(p<0.05)$

${ }^{a, a}$ Superscripts in column did not differ significantly $(p>0.05)$
TABLE II: Gastrointestinal parasites and associated worm burden among African giant rats (Cricetomys gambianus) examined in the semi-arid region of northeastern, Nigeria

\begin{tabular}{|c|c|c|c|c|}
\hline $\begin{array}{l}\text { No. } \\
\text { Examined }\end{array}$ & $\begin{array}{l}\text { No. } \\
\text { Infected }\end{array}$ & $\begin{array}{l}\text { Various species of } \\
\text { gastrointestinal } \\
\text { parasites } \\
\text { recovered (\%) }\end{array}$ & $\begin{array}{l}\text { Predilection } \\
\text { sites }\end{array}$ & $\begin{array}{l}\text { Post - mortem } \\
\text { worm counts } \\
\pm \text { S.D. }\end{array}$ \\
\hline 100 & $38(38 \%)$ & $\begin{array}{l}\text { (i) Hymenolepis nana } \\
19(50 \%)^{a} \\
\text { (ii) Strongyloides } \\
\text { stercoralis } 7(18.42 \%)^{b} \\
\text { (iii) Aspicularis tetraptera } \\
5(13.16 \%)^{c} \\
\text { (iv) Ancylostoma caninum } \\
4(10.53 \%)^{d} \\
\text { (v) Taenia species cysts } \\
3(7.89 \%)^{d}\end{array}$ & $\begin{array}{l}\text { Small intestine } \\
\text { Large intestine } \\
\text { Rectum/colon } \\
\text { Small intestine } \\
\text { Abdominal } \\
\text { cavity }\end{array}$ & $\begin{array}{l}255.6 \pm 0.07^{a} \\
126.5 \pm 0.05^{b} \\
105.2 \pm 0.05^{b} \\
76.4 \pm 0.04^{c} \\
8.0 \pm 0.01^{d}\end{array}$ \\
\hline & Total & $38(38.0)$ & & $1,267.7 \pm 0.22$ \\
\hline
\end{tabular}

${ }^{a, b, c, d}$ Superscripts in columns differed significantly $(p<0.05)$

TABLE III: Ectoparasites encountered among African giant rats (Cricetomys gambianus) examined in the semi-arid region of northeastern, Nigeria

\begin{tabular}{|c|c|c|c|}
\hline $\begin{array}{l}\text { No. } \\
\text { Examined }\end{array}$ & $\begin{array}{l}\text { No. } \\
\text { Infested }\end{array}$ & $\begin{array}{l}\text { Various species } \\
\text { of ectoparasites } \\
\text { recovered (\%) }\end{array}$ & $\begin{array}{l}\text { Parasite counts } \pm \\
\text { S.D. }\end{array}$ \\
\hline 100 & $22(22 \%)$ & $\begin{array}{l}\text { (i) Rhipecephalus sanguineus } \\
11(50 \%)^{a} \\
\text { (ii) Ctenocephalides canis } \\
3(13.64 \%)^{b} \\
\text { (iii) Xenopsylla cheopis } \\
5(22.73 \%)^{c} \\
\text { (iv) Polyplax serrata } \\
2(50 \%)^{a} \\
\text { (v) Ixodes rasus } \\
1(4.55 \%)^{d}\end{array}$ & $\begin{array}{l}125.2 \pm 0.12^{a} \\
11.4 \pm 0.04^{b} \\
100.5 \pm 0.10^{a} \\
10.6 \pm 0.03^{b} \\
4.0 \pm 0.02^{c}\end{array}$ \\
\hline & Total & $22(22.0 \%)$ & $251.7 \pm 0.31$ \\
\hline
\end{tabular}

$a, b, c, d$ Superscripts in second column differed significantly $(p<0.05)$ ${ }^{a, b, c}$ Superscripts in third column differed significantly $(p<0.05)$

TABLE IV: Haemoparasites encountered among African giant rats (Cricetomys gambianus) examined in the semi-arid region of northeastern, Nigeria

\begin{tabular}{l|l|l|l}
\hline $\begin{array}{l}\text { No. } \\
\text { Examined }\end{array}$ & $\begin{array}{l}\text { No. } \\
\text { Infected } \\
\text { (\%) }\end{array}$ & $\begin{array}{l}\text { Various species } \\
\text { of haemoparasites } \\
\text { encountered (\%) }\end{array}$ & $\begin{array}{l}\text { Parasite counts } \\
\pm \text { S.D. }\end{array}$ \\
\hline 100 & $25(25 \%)$ & $\begin{array}{l}\text { (i) Hepatozoon muris } \\
13(52 \%)^{a} \\
\text { (ii) Eperythrozoon coccoides } \\
4(18 \%)^{b}\end{array}$ & $98.2 \pm 0.08^{\mathrm{a}}$ \\
& $\begin{array}{l}\text { (iii) Haemobartonella muris } \\
8(32 \%)^{c}\end{array}$ & $14.3 \pm 0.03^{\mathrm{b}}$ \\
\hline & Total & $25(25.0 \%)$ & $174.9 \pm 0.18$ \\
\hline
\end{tabular}

${ }^{a, b, c}$ Superscripts in third column differed significantly $(P<0.05)$

${ }_{a, b, c}$ Superscripts in fourth column differed significantly $(P<0.05)$

Table III shows the various species of ectoparasites encountered among the African 
giant rats examined. Out of the 22 infested rodents, 11(50\%) harboured Rhipicephalus sanguineus with a mean count of $125.2 \pm 0.12$ while 3(13.64\%) harboured Ctenocephalides canis with a mean count of $11.4 \pm 0.04$, $5(22.73 \%)$ had Xenopsylla cheopis with a count of $100.5 \pm 0.10$. Similarly, 2(50\%) harboured Polyplax serrata and $1(4.55 \%)$ had Ixodes rasus with a count of $10.6 \pm 0.03$ and $4.0 \pm 0.02$ respectively. Table IV shows that Hepatozoan muris were found in $13(52 \%)$ with a mean count of $98.2 \pm 0.08$, Eperythrozoon coccoides in $4(18 \%)$ with a count of $14.3 \pm 0.03$ and Hamobartonella muris in $8(32 \%)$ with a count of $62.4 \pm 0.07$.

\section{DISCUSSION}

The endo, ecto and haemoprasitic infections of the African giant rat (Cricetomys gambianus) is being reported for the first time in the semi-arid region of northeastern, Nigeria. Meanwhile, Chineme and Ibrahim (1994) had reported an incidence of hepatic capillariasis in giant rats in the guinea Savannah of Nigeria. Similarly, parasites of the giant rat were studied, extensively in Southwestern, Nigeria (Dipeolu and Ajayi, 1976; Ajayi, 1977; Ajayi et al., 1978) and recently in Eastern, Nigeria by Okoye and Rose (2008).

In this present study, several species of gastrointestinal parasites such as Hymenolepis nana, Taenia species cysts and Strongyloides stercoralis were recovered from giant rats in the area. The implication of this result is that, the wild rodents may serve as a reservoir of internal parasites of medical importance. Strongyloides stercoralis, commonly called the "threadworm" of the family Rhabditoidea, is known to cause severe diarrhoea in infants and immunocompromised individuals (William, 2001). The giant rat in the semi-arid region of Northeastern, Nigeria also harbours Ancylostoma caninum which is of veterinary importance and causes anaemia, weakness and stunted growth in canines (Soulsby, 1982) while in humans, the larvae are associated with cutaneous larval migrans (William, 2001). The occurrence of cysts of Taenia in the abdominal cavity of the giant rats signifies the possible role of the rodents as intermediate hosts to human parasites. Claude et al. (2005) also reported the presence of Taenia serialis cysts in wild African giant rats (Cricetomys gambianus) at necropsy in the United States of America. Haepatozoon muris was the most commonly encountered haemoparasite among the giant rats. It is a common haemoprotozoan of the brown rat (Rattus rattus) and the black rat (Rattus norvegicus) (Soulsby, 1982). The developmental cycle of the parasite is completed in the rat louse; Echinolaepis echidninus and the rats are often infected by ingestion of the louse. Other haemoparasites encountered were Haemobartonella muris and Eperythrozoon coccoides. The occurrence of Haemobartonella muris and the absence of its natural vector, Polyplax spinulosa in this study, may mean that Polplax serrata may be the possible vector in this case. However, the presence of Polyplax serrata may explain the presence of Eperythrozoon coccoides in the blood of the giant rats. This rat louse is an established vector of Eperythrozoon coccoides in laboratory mice (Soulsby, 1982). Among the ectoparasites encountered, the "brown dog tick", Rhipicephalus sanguineus and Polyplax serrata were the commonest followed by the "oriental rat flea", Xenopsylla cheopis, the "dog flea", Ctenocephalides canis then lastly, the "hard tick", Ixodes rasus. Some of these parasites have been reported in giant rats in other regions (Dipeolu and Ajayi, 1976; Ajayi, 1977; Bobe and Mabella, 1997; Kingdon, 1989). The occurrence of Rhipecephalus sanguineus and Ctenocephalides canis in the rats, could suggest its possible reservoir status as a source of infection to dogs. Rhipecephalus sanguineus has been reported to cause severe anaemia and tick paralysis in dogs and transmits canine babesiosis and canine ehrlichiosis in domestic dogs (Soulsby, 1982; William, 2001) and spotted hyena (Crocuta crocuta), striped hyena (Hyena hyena) and jackal (Canis aureaus) (Mbaya et al., 2006; 2008). Ctenocephalides canis, which equally infest dogs (Soulsby, 1982) and wild Canidae (Mbaya et al., 2006; 2008) transmits Dipylidium caninum, tularaemia and plague (William, 2001; Cooper, 2008). In this study, it was observed that statistical variation $(\mathrm{P}<0.05)$ existed in the prevalence of endo, ecto parasitic infections according to age. With gastrointestinal infections, adults were more infected, which was probably associated with the fact that they roam more than the juveniles in search of food and territorial dominance. With ectoparasitic infestations, why the juveniles were more 
infested, might be associated with age susceptibility (Soulsby, 1982). In conclusion, the results showed that the African giant rat harboured endo, ecto and haemoparasites of medical and veterinary importance. The rat's close association with human dwelling may as well ensure a 'synantropic-zoonotic association.

\section{ACKNOWLEDGEMENTS}

The authors are grateful to the staff and Management of Sanda Kyarimi Park, Commandant of Maimallari Military Barracks, Maiduguri and Mallam Yauba and Ali Mohammed for their technical assistance.

\section{REFERENCES}

AJAYI, S. (1977): Field observation on the African giant rats (Cricetomys gambianus) in Southern Nigeria. East Afr. Wldlife J. 15(3): 191-198.

AJAYI, S., TEWE, O. and FATUROTI, E. (1978): Behavioural changes in African giant rats (Cricetomys: water house) under domestication. East Afr. Wldlife J. 16(2): 137143.

ANNE, H. (2009): Rat lungworm: Parasite brain infection disease turning up in Hawaii and New Orleans, Spread by eating unwashed vegetables. Parasitol. 1: 772-773.

AUDU, R.A., MOHAMMED, A., IBRAHIM, N.D.G. and MOREH, E.B. (2008): Histopathological studies on Trypanosoma brucei infected African giant rats (Cricetomys gambianus, Waterhouse). Int. J. of Pure and Appl. Sci. 2(3): 84-89.

BOBE, L. and MABELA, M. (1997): Incidence of four gastrointestinal parasite worms in-group of Cricetomas, Cricetomys gambianus (Rodents: Cricetidae, caught in Lukaya, Democratic Republic of Congo. Trop. 15(3): 132-135.

BOURN, D., WINT, W., BIEUCH, R. and WOOLLEY E. (1994): Nigerian livestock resources survey. Wld Anim. Rev. 78: 49-58.

BROOM, S. and LEGGE, D. (2004): Animal welfare Vs free trade wins: an experimentation of the animal welfare Implications. Ministry of Agriculture, Fisheries and Food compassion farming. Anim. Welfare (9): 81 85.

CHINEME, S.N. and IBRAHIM, M.A. (1994): Hepatic capilliriasis in African giant rat. J. Wldlife Dis. 20(4): 341-342.

CLAUDE, L., ERIKA, T., KATHRYN, C.G. and THOMAS, C. (2005): Cestodes cysts in two African giant rats (Cricetomys gambianus). J. Zoo and wldlife Med. 36 (1): 95-99.
COOPER, R.G. (2008): Care, husbandry and diseases of the African giant rat (Cricetomys gambianus). J. South Afr. Vet. Assoc. 79(2): 62-66.

DIPEOLU, O. and AJAYI, S. (1976): Parasites of the African giant rats Cricetomys gambianus in Ibadan, Nigeria. East Afr. wldlife J. 14(1): 85-89.

ELUMERE, E. O. (1987): Motivation and learning geography in senior secondary school in Bama Local Government. Unpublished, post-graduate diploma thesis in education, University of Port Harcourt, Nigeria, pp. 1-234.

HANSEN, J. and PERRY, B. (1994): The Epidemiology, Diagnosis and Control of Helminth Parasites of Ruminants, $2^{\text {nd }}$ Edition. International Laboratory $\mathrm{f}$ o $\mathrm{r}$ Research on Animal Diseases (ILRAD): Nairobi: 57-93.

JOO, M. and MYERS, P. (2004): "Cricetomys gambianus" (online), Animal Diversity Web accessed, August 27, 2008 at htt:// animal.diversity ummz.umich.edu/site/accounts/information/cricetomys gambianus.html.

KINGDON, J. (1989): East African Mammals. London, New York: Academic Press: 45-47.

LEVINE, N. D. (1973): Protozoan parasites of domestic animals and man. Burgess Publishing Company, Minneapolis: 133-155.

NOWAK, R. (1997): "Mammals of the world" (online). Accessed March 28, 2004 at htt://wwwpressjhu.edu/books/walkers mammals of the world /rodentia/rodentia muridae.crice.

MAED, R. and CURNOW, R.N. (1983): Statistical methods in Agriculture and Experimental Biology, Chapman and Hall: London, UK: 100-120.

MBAYA, A.W., NWOSU, C.O., ALIYU, M.M. and AHMED, T.A. (2006): A comparative study of gastrointestinal parasites of captive and free-living wild animals in the semi-arid zone of northeastern Nigeria. Nig. J. Exp. Appl. Biol. 7(2): 185-193.

MBAYA, A.W., ALIYU, M.M., NWOSU, C.O. and IBRAHIM, U.I. (2008): Captive wild animals as potential reservoirs of haemo and ectoparasitic infections of man and animals in the arid region of northeastern Nigeria. Vet. Arh. 78(5): 429-440.

OKOYE, I. C. and ROSE N. N. (2008): Survey of the gut parasites of rodents in Nsukka Ecological Zone. Anim. Res. Int. 5(2): 846-847.

PRATT, P.W. (1987): Laboratory Procedures for Animal Health Technicians, $1^{\text {st }}$ Edition. American Veterinary Publication Inc, USA: 56-59.

SOULSBY, E.J.L. (1982): Helminths, Arthropods and Protozoa of DomesticatedAnimals, $7^{\text {th }}$ Edition. Bailliere, Tindall and Company, London: 809-810.

WILLIAM, J.F. (2001): Veterinary Parasitology, Reference Manual, $5^{\text {th }}$ Edition. Blackwell, Publishing, Iowa, State University: 8-25. 